\title{
Developing Cultural Awareness
}

\author{
İsmail Firat ALTAY
}

ifaltay@hacettepe.edu.tr

\begin{abstract}
This paper aims at emphasizing the issue of teaching of culture in foreign language teaching. In this respect, the reasons of teaching culture in foreign language classes are focused on initially. So, the justifications of teaching culture are considered and explained and by the help of a dialogue. Right after this, ways of developing cultural awareness is taken into account. At this step, types of courses to develop cultural awareness are dealt with. Developing cultural awareness in class is another aspect to handle. Besides, ways of developing cultural awareness outside the class are worked on. Whether there are dangers of using culture in foreign language class is explained in dangers and problems part. In the conclusion, ideas of the writer on the subject as final remarks are clarified.
\end{abstract}

Key Words: Culture, teaching of culture, cultural awareness, developing cultural awareness

\section{Özet}

$\mathrm{Bu}$ makale yabancı dil öğretiminde kültür öğretimi konusunu vurgulamayı amaçlamaktadır. Bu anlamda ilk olarak yabancı dil sınıflarında kültür öğretiminin nedenleri üzerinde durulmuştur. Böylece, kültür öğretiminin sebepleri örnek bir diyalogun da yardımıyla irdelenmiştir. Bundan sonra, kültürel farkındalığın geliştirme yolları ele alınmıştır. Bu aşamada kültürel farkındalığı arttırmak için faydalanılacak ders türleri, sınıf içinde ve sınıf dışında yapılması gereken aktiviteler işlenmiştir. Yabancı dil sınıfında kültür öğretmenin sorunlara sebebiyet verip vermediği sorusuna ise bir sonraki bölümde cevap aranmıştır. Sonuç bölümünde ise yazar, konu üzerinde kendi düşüncelerine yer vermiş ve dikkat çekilmesini gerekli gördüğü noktaları öne çıkarmıştır.

Anahtar kelimeler: Kültür, kültür öğretimi, kültürel farkındalık, kültürel farkındalığı geliştirme 


\subsection{INTRODUCTION}

In the field of foreign language learning and teaching there are some issues that are indispensable from teaching and learning process. One of them is culture. As far as culture is the matter of debate, teaching of culture and cultural awareness come to mind. The reason is that in communication, cultural understanding or intercultural communication are of utmost importance, and without mastery on them, a complete foreign language learning and teaching atmosphere cannot be realised. But what is culture?

Longman Dictionary of Contemporary English defines culture as "the ideas, beliefs, and customs that are shared and accepted by people in a society" (1995: 330). In another definition, culture is presented as the way of life. Since the way of life changes from society to society, in learning a foreign language, one should consider the culture of the target language speakers in order to develop an intercultural communication bridge and have a better, mutual perlocutionary understanding of concepts.

Researchers also believe that "language and culture are not separable but acquired together, with each providing support for the development of the other" (Mitchell and Myles, 1998:183).

As Mitchell and Myles quoted from Ochs:

"It is evident that acquisition of linguistic knowledge and acquisition of cultural knowledge have significant importance. A basic task of the language acquirer is to acquire tacit knowledge of principles relating linguistic forms not only to each other but also to referential and non-referential meanings and functions... Given that meaning and functions are to a large extent socioculturally organised, linguistic knowledge is embedded in sociocultural knowledge. On the other hand, understanding of the social organisation of everyday life, cultural ideologies, moral values, beliefs, and structures of knowledge and interpretation are to a large extent acquired through the medium of language... Children develop concepts of a socioculturally structured universe through their participation in language activities".

Cultural awareness increases person's intentional and purposive decision making ability by accounting for the many ways that culture influences different perceptions of the 
same situation. As Pederson states, "Developing cultural awareness is not an end in itself but rather a means toward increasing a person's power, energy and freedom of choice in a multicultural world" (1998:3). In this respect, intercultural communication is realised and culture shock and related problematic situations are eliminated.

\subsection{WHY TEACHING CULTURE?}

The reasons for developing cultural awareness and culture teaching were touched upon beforehand. Simply, it can be declared that if cultural awareness is not realised in foreign language classes, primarily the communication and secondarily the personality of the learners may be affected negatively. Teaching of culture is a must if the answers to the following questions are not yes as Pedersen (1988) states:

- Is the learner aware of differences in cultural institutions and systems?

- Is the learner aware of the stress resulting from functioning in intercultural situation?

- Does the learner know how rights or responsibilities are defined differently in different cultures?

- Is the student aware of differences in verbal and nonverbal communication styles?

- Is the student aware of significant differences and similarities of practises across different cultures?

If the answers to these questions are all 'no' or mostly 'no', than the foreign language learner is in need of help. Culture shock is very close to him because of the force of his identity. If he cannot have some kind of support, he can suffer from anomie. So, cultural awareness must be developed to overcome these problems.

At this step, goals of teaching culture must be specified. Rivers (1981) lists seven goals of cultural instruction toward which classroom activities and materials should be directed. Learners should be able to demonstrate that they have acquired certain understandings, abilities and attitudes: 
1. That they understand that people act the way they do because they are using options the society allows for satisfying the basic psychological needs;

2. That they understand that such social variables as age, sex, social class and place of residence affect the way people speak and behave.

3. That they can demonstrate how people conventionally act in the most common mundane and crisis situations in the target culture.

4. That they are aware that culturally conditioned images are associated with even the most common target words and phrases.

5. That they are able to evaluate the relative strength of a generality concerning the target culture in terms of the amount of evidence substantiating the statement.

6. That they have developed the skills needed to locate and to organise material about the target culture from the library, mass media and personal observation.

7. That they possess intellectual curiosity about the target culture and empathy toward its people.

From another point of view, if cultural aspects of the target foreign language or the goals are not considered, communication breakdowns may occur in genuine dialogues with a great burden of culture. Let's have a look at the following dialogue:

A: What's up John? You still got the blues?

B: Yea, right. Again I am cross with my girl.

A: What's the matter, brother?

B: You know I tricked her, I thought that she would not get it. But I got sting in the tail.

It may be difficult to have a complete understanding of the given dialogue since it possesses some kind of cultural information. A careful study of culture of this text may give clues about the cultural background, education, ethnicity and worldview of the people talking. In addition without knowing some terms used in the text, it does not seem possible to have comprehension of the dialogue. No matter how good one is in his linguistic, pragmatic or discourse knowledge, without having the mastery of culture of the target language, that is awareness of foreign language, desired aims are not reached. 
Such dialogues may be seen in different forms in every aspect of our lives: either in coursebooks or on the street. So, the learners should be ready to understand there language fragments. Here, the only way seems to be developing cultural awareness for intercultural communication. But how can this be realised? The answer to this question is going to be focused on in the next part of this paper.

\subsection{HOW TO DEVELOP CULTURAL AWARENESS IN EFL CLASSES?}

Cultural awareness can be developed in different ways. As far as higher level of learners is concerned, some course types may be the matter of question. Learners are offered courses directly concerned with the culture of the target language society.

\subsection{Types of Courses for Cultural Awareness}

Rivers (1981) points out courses for the development of cultural development in order to have a kind of intercultural communication in the following articles:

1. A sequenced presentation of all aspects of the culture with reading, exposition, discussion illustration by films, slides, maps and other visual means and personal research objects. A course of this type is usually conducted in the target language.

2. A contrastive study of target culture and the culture of the language learners. Similar means are used to those for course 1. Readings and other informational material may be in either language. Students study articles on the same subject by representation of the two cultures, what each says about the other, how newspapers and magazines from the two cultures vary in their interpretation of events and in the kinds of materials they present, how writers and poets deal with similar themes in the two cultures, and so on. The course is often conducted in the native language of the students, with much of the reading and some of the explanations in the foreign language.

3. Interdisciplinary courses in which students study the history, sociology, fine arts, or philosophy of the country or countries where language is spoken. Learners read and study original documents in the language. The course may be given in the target or native language. 
4. A conversationally oriented course in which students learn much about the country and the culture so that they may interact orally in a more effective and sympathetic way with speakers of the language. All activities are conducted in the target language and are closely linked with situations in the target culture. In this case, both students and teachers use the target language.

5. Contemporary culture studied through literary texts. These are chosen to illustrate themes or values of the culture as well as for their specific literary quality. Literature is taken in its broadest sense, and the course may include popular fiction, folklore, ballads, children's rhyme and anything else that can illuminate the thought and life experience in the culture. The course may be conducted in the target language or in the language of the students, although the former is more common.

6. A course similar to the one mentioned in article five will use films as the medium of study of the culture for the development of cultural awareness. Again films are selected which are representative of aspects of life in the culture, not those which reflect untypical behaviour or situations. The films will be in the target language. Target or native language will be used for discussion, depending on the types of students attracted by the course.

\subsection{Developing Cultural Awareness in Class}

Apart from advanced level, in other levels, cultural awareness may be developed in class atmosphere. In this part of the paper, these class activities will be stated.

\section{Describing and explaining culture:}

In the past, the most common method for developing cultural awareness was exposition and explanation. Teachers have talked about the target language speaking community or communities. Their history, literary, scientific or artistic achievements were told. They could be supported by visual materials. 


\section{Experiencing the culture through language use:}

Through language use, students become conscious of correct levels of discourse and behaviour: formulas of politeness and their relation to the social attitudes of people, appropriateness, turn takings, etc are considered here. Gradually, learners begin to perceive the expectations within the society and the values. From the beginning, the teacher should orient the thinking of learners.

\section{Dialogues, skits and mini dramas, drama games:}

One of the most common devices used in the early stages is dialogues. A carefully constructed dialogue lends itself to acting out culturally based situations. Each dialogue should be constructed to demonstrate behaviour culturally appropriate for speakers of that language. As the students become familiar with the dialogue and act it out, they learn through role-playing how to interact with all kinds of people.

Drama games are usually utilised for young learners, but they are also applicable for older learners since they can be used with them only with a few minor changes. Picture making, dubbing, ear to ear, Simon says that and walking are among the well-known drama games. They have a very significant motivating effect in addition to their skill development and cultural awareness development duty. Young learners just learning a new language may be affected from such a situation positively. So, they will have a kind of positive intuition about target language. These kinds of games also meet the needs of young learners who require some activities to spend their energy.

\section{Masks and puppets:}

Masks and puppets may be of great use especially for young learners. These devices protect the participants from violating their own codes of behaviour or appearing foolish to their peers, because it is clear that it is not they but the modelled characters that are responsible for what is expressed or performed. Social attitudes and implicit values of another culture can often be achieved by use of masks in the role playing or by representing through puppets.

\section{Role play and simulation:}

Role play is perhaps the most well known cultural awareness developing activity among all the others. It can be applied in any class easily, and only with a few simple modifications it can be used for different levels. Role play, like other drama activities, involves an element of 
'let's pretend in the target culture. That is to say, they either can play themselves in imaginary situations, or they can be asked to play imaginary people in an imaginary situation. Both of these two pretending situations can easily be utilized in class as a cultural awareness developing activity. These activities give the students a chance to get up and move after long lecture hours which may be very boring for them and are familiar with the culture of the target language.

Simulation is really a large scale role play. Or, simulation can be defined as "an activity where the learners discuss a problem, perhaps a series of problems, with a defined setting." (Byren, 1990:125). That is to say, in addition to role play, in simulation some background information is given in addition. The intention is to create a much more complete and complex world in target culture such as a business company, a television studio, the office of the government... etc.

In simulation, in contrast to role play, the number of the participants is much higher. For example, in a role play activity there are usually two, three or at most four or five students taking place. However, the goodness of the simulation is that, in such an activity a whole class can take part. Imagine a situation where there is a discussion programme and there are five guests to discuss the matter. There are ten journalists who will ask questions to the guests, and the rest of the class is the audience who will also ask questions either to the guests or to the journalists. So, there is a debate situation which is enjoyed by learners while acquiring the culture of the target language speaking communities.

\section{Songs and dances:}

Songs and dances help a lot about culture. The reason is that dances and songs have codified cultural fragments in their structure. Since they have joy and fun, culture is presented between the lines. Songs and dances also help learners see different world views and traditions. Thus, sympathy for foreign cultures is actualised.

\section{Native speakers in the class:}

If possible, gathering with native speakers in class helps a lot. When the learners have such an experience, they have the chance of getting direct culture equipped language. So, they use their linguistic competence with cultural and discourse competence. 


\section{Using the bulletin board and keeping up with the news:}

Another means of making life in the country or countries where the language is spoken seem real and contemporary is the keeping of an up-to-date bulletin board in foreign language classroom. By the help of the news, cultural events, and achievements of the countries presented on the board, the learners will be exposed to the target culture. Proverbs, comic strips, carefully selected jokes may be exhibited on the board.

The daily news is a rich source for cultural information. What happens in the target language speaking community or communities may be interesting for learners. Discussions on the news are of great use. Television, radio, newspapers and finally internet have great influence on the development of cultural awareness of the foreign language learners.

\section{Using pictures, films, filmstrips and video:}

Pictures are speaking materials in fact. They present a lot more than many other devices as far as culture is concerned. Suitable pictures with authentic setting are available for language classes for a variety of countries. Pictures, like other visual materials, let learners see the target language speaking societies in their settings. So, some concepts become more concrete. The same thing applies for films and filmstrips or video. They make a war away culture concrete and reachable.

\subsection{Developing Cultural Awareness outside Class}

In some situations in class activities to develop cultural awareness may fall short, and some other ways may be necessary. In this way, cultural learning lets itself go out of the limits of class. Some of these outside class activities for developing cultural awareness are as follows:

\section{Pen pals and tape exchanges:}

Pen pals and tape exchanges give the students a chance to make personal contact with someone of their own age. Thus, they get to know the speaker of the foreign language from a personal point of view. They can ask questions, share interests and have a strong contact. 


\section{Student exchanges:}

For those students who have linguistic ability, interest, time and money, the opportunity to study abroad is a good chance. This can be a direct contact to the foreign language speaking community. Exchange programmes like Socrates - Erasmus are very useful for those who do not have personal monetary support.

\section{Summer camps and language festivals:}

By the help of short period summer camps and language festival, learners may have the chance to see target language speaking communities. They will have one to one contact again. If special organisations to help language learning, they can be made use of as well. However, initially, cultural awareness is considered.

\subsection{DANGERS AND PROBLEMS}

In the composition of dangers and problems related to the teaching of culture, first possible dangers will be handled. One danger in teaching culture is that language teachers may attempt to teach culture when they do not have the knowledge or expertise to do so. Such attempts may do more harm than good. If the target culture is presented in such a way that false impression arise, the alternative of no culture is preferable.

The second danger is the amount of work done in the mother tongue in many classes in which the teacher stresses culture. While few foreign language teachers would currently recommend banning mother tongue use, work done in the mother tongue does not lead to foreign language communication skills. The linguistic level of activities may affect the ongoing of this situation, as well.

The third danger is that "the culture content selected for the class may concentrate on the unusual, the bizarre and esoteric to the exclusion of the basic characteristics of the culture. Culture activities should not be turned into some sort of circus freak show" (Chastain, 1988:317). The teacher may contribute to such a situation by concentrating on the differences between the cultures rather than on the total picture of any given culture segment. In order to avoid confusion and misunderstanding, the teacher should describe all aspects of the situation. 
After the dangers in teaching culture, the problems in teaching it come. The first problem is how to provide culture information. Many teachers, through no fault of their own, are simply not equipped to teach culture. If the goals, definitions, organisation and techniques are provided, the teacher can incorporate teaching-learning activities for cultural objectives. But this can be realised only if the answer to the question 'What to teach?' can be found. Even those teachers who have visited or studied abroad may have overlooked many basic customs among the people. So, without previous preparation and direction in planning what to look for, the visitor may gain relatively few insights into the foreign culture during a stay in the foreign language or target language community. Guidelines need to be provided and observation must be done in order to shape what to teach.

Language teachers need assistance in overcoming their lack of knowledge about the target culture. Firstly, in cultural studies they need help from experts who can identify them basic characteristics of the target culture. This can be presented in undergraduate and inservice programmes. Secondly, they need help from the commercial publishers who can produce materials containing much of the information they need to know. Third, they may need from colleges and university members for further training programmes in order to overcome their lack of expertise in culture.

The second major problem is how to devise ways of presenting culture in such a manner that the students can comprehend and relate to the information. Culture content must be presented at a level and in a manner to which the students can attach some relationship between the information and their own background experiences. This is not something easy. In order to realise this, the advantage of visualisation and dramatisation is necessary.

The third problem is that of finding time in the class period to include culture. The first point regarding this problem is that many of the described techniques take relatively little class time. The second point is that even if they do take more time than the teacher may desire, the ends justify the means in this case. So, more time can be spent on culture without weakening the students' language skills, because culture will help them to use combine their language skills with communicative skills in order to have a complete mastery of communication. 
Besides, while trying to make learners aware of the target culture, because of ethnolinguistic identity theory, learners may be completely against the target language culture. They may reject all foreign customs and way of life. If the learners are exposed to foreign culture though they are against it, culture shock may be in the agenda. The learner suffers from culture shock. This situation affects both his personal life and linguistic success. Even further cases may lead to anomie.

\subsection{CONCLUSION}

As a consequence, teaching of culture is necessary and very useful and should never be neglected. However, this is not easy and a bit problematic. Even after working on this issue, some points need further clarification, and they will be discussed here.

No doubt culture should be taught while teaching a foreign language. On the other side, when English language is the core of the question, which language should be considered as the target culture? English (or British?), American, Australian, New Zelandian or other cultures? Today English is spoken all over the world. Half of the world mail is in English. So, is there any specific culture to handle while teaching it? The answer is not clear, but most scholars agree on the point that the culture of the countries where this language is spoken as mother tongue should be considered so as to teach. However, there may a more heated discussion on this issue in the future.

Secondly, are in-class activities enough to teach the culture of the target language? Saying 'yes' to this question is not an easy matter. So, what can be done as out of class activities? Pen pals and tape exchanges, travelogue films, summer camps, student exchange and travel or study programmes, use of community resources and language festivals can be considered as out of class activities where culture tan be taught in addition to in class activities. Thus, efficiency can be increased.

To sum up, teaching of culture is very necessary in the framework of teaching of a language. However, while doing this, learners should not be aliens to their own culture which may end in assimilation. Thus, language teachers should also be very careful in dosing this culture teaching issue, and our own culture should be preserved while learning another 
culture. No doubt doing this passes from the ways of being a skilled teacher, and we should try to be a skilful teacher as much as possible.

\section{BIBLIOGRAPHY}

Brown, D. H. 1994. "Principles of Language learning and Teaching” Englewood Cliffs: New Jersey.

Byren, D. 1990. “Teaching Oral Skills” London: Longman.

Chastain, K. 1986. "Developing Second-Language Skills" Orlando: Harcourt Brace Jovanovich.

Crystal, D. 1987. "The Cambridge Encyclopaedia of Languages" Cambridge: Cambridge University Press.

Kramsch, C. 2001. "Context and Culture in Language Teaching” Oxford: OUP.

Mitchell, R. and Myles, F. 1998. "Second Language Learning Theories." North Yorkshire: Replika Press.

Öktem, Ö. 2000. “The Negative Cross-cultural Factors in Acquiring Proficiency in a Foreign Language” M. A. Thesis. Ankara: Hacettepe Üniversitesi.

Pedersen, P. 1988. "A Handbook for Developing Multicultural Awareness" Alexandria: American Association for Counseling and Development.

Rivers, W. M. 1981. "Teaching Foreign Language Skills" Chicago: The University of Chicago Press.

Stern, H. H. 1991. "Fundamental Concepts of Language Teaching" Oxford: Oxford University Press.

Ismail Firat ALTAY is a research assistant at Hacettepe University, Faculty of Education, Foreign Languages Teaching Department, Division of English Language Teaching E-mail: ifaltay@hacettepe.edu.tr 